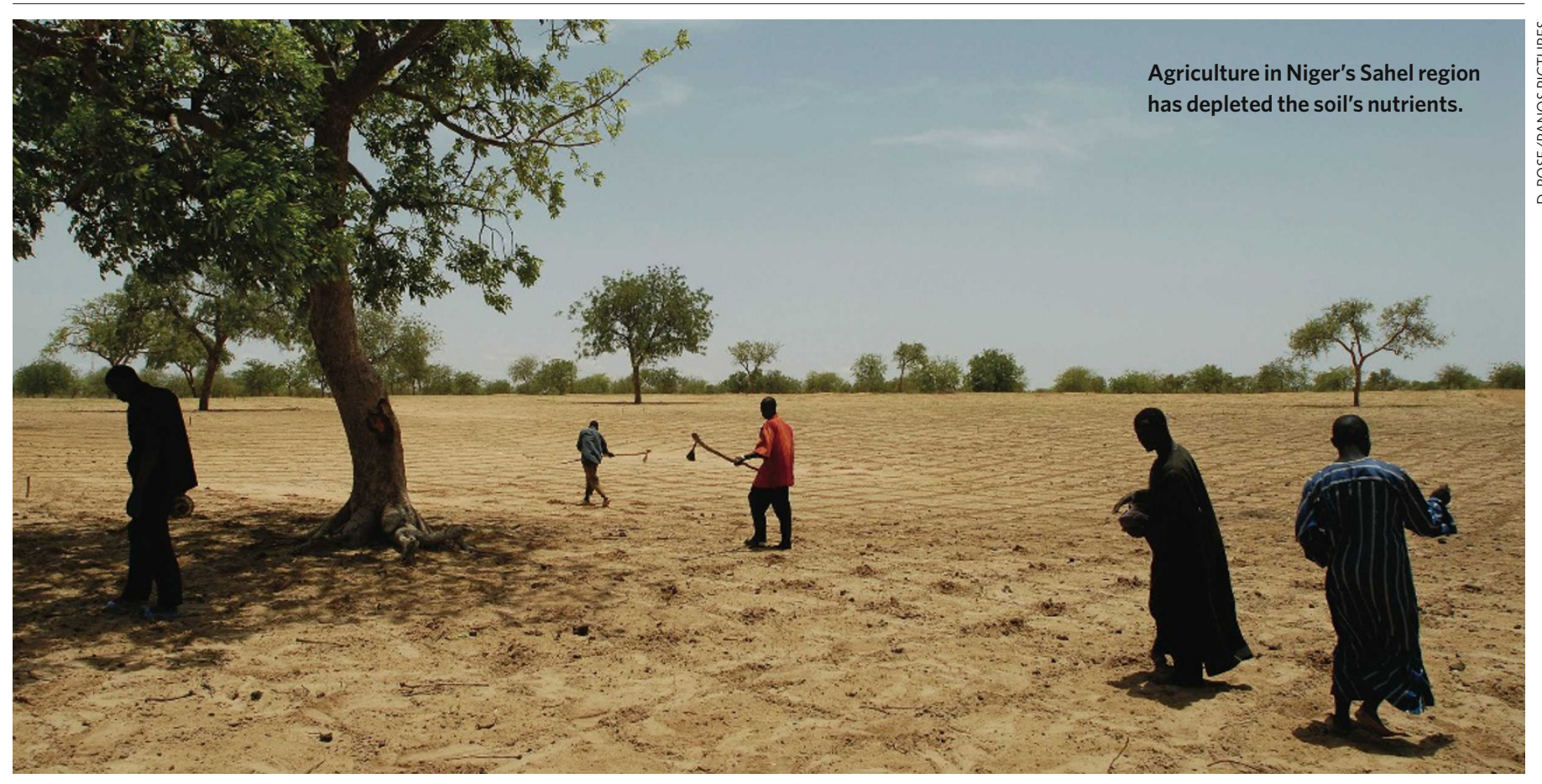

\title{
Exhibition digs deep to save our soils
}

\section{Dig It! The Secrets of Soil \\ Smithsonian National Museum of Natural History, Washington DC \\ Until 3 January 2010}

Soil is more than mere dirt beneath our feet. It holds the nutrients that produce our food. More carbon is sequestered in soil than in all the plants on Earth, and its role as a carbon sink is becoming increasingly important as atmospheric carbon dioxide levels rise. A shovelful of soil can house more creatures, including earthworms, insects and microbes, than there are humans on Earth.

Dig It! The Secrets of Soil, a new exhibition showing at the Smithsonian Institution's National Museum of Natural History in Washington DC until January 2010, explores the science of Earth's skin with dioramas, videos and hands-on demonstrations.

Visitors can admire samples of the rocky black land of Texas, the chunky red soil of North Carolina, and earth from 52 other US states and territories. Red or yellow often indicates iron compounds, and black can signify manganese. Also offered are 'mystery soils' for sleuths to identify from a series of clues.

Most fun are the videos that put a soil spin on hit television series. In the animation Chef's Challenge, two soil cooks battle to make a pleasing ecosystem from the secret ingredient - sand. One chef offers up a forest; another a bog. Judging between the two recipes are a turtle, a bird and a methane bubble called Gassy Gallagher. Naturally, Gallagher votes for the bog.

On another screen, the Soil Science Investigators look into the disappearance of a 45-kilogram blue ribbon pumpkin called Linus. Soil microbes in the pumpkin remains found at the crime scene help to estimate Linus's time of death, and wheelbarrow tracks reveal that the barrow passed through a forest. "Soil. It's the greatest. Tells us how things grow, how things die," intones Detective Clay. Oddly, though, the clue that finally cracks the caper isn't found in soil, but flour.

These fun skits hold serious messages. Soils take millennia to form, and their recipes are far from simple. But soils can be destroyed in decades.

Most life resides in the top few centimetres, and the majority of soil organisms remain unknown to science. Those that have been identified provide services as diverse as transferring nutrients between the air and plant roots, recycling dead creatures and making antibiotics such as penicillin.

Soil requires a delicately balanced chemistry to support its complex ecosystem of plants, animals, bacteria and fungi. Agriculture, in particular, strips nutrients from the topsoil and plants struggle when those nutrients are not replenished. Adding fertilizer and leaving fields fallow can help revitalize them, but that isn't an option for poor farmers. In south Asia, people rely on manure and plant matter for fuel, so those nutrients are not recycled back into the soil. Pollution from irrigation water damages the land further.

More than two-thirds of Africa's soils are depleted, notably in Niger's Sahel region. People, animals and agriculture have destroyed native plants that held the soil in place. Water now flushes the soil away, and with it the nutrients for the farmer's crop.

The globe has faced thinning soils before; civilizations have fallen because their agriculture degraded the land. Ancient Mesopotamian city-dwellers diverted river water to irrigate fields. As it evaporated, mineral salts were left behind, making the land too salty for crops. Some suggest that California's San Joaquin Valley, which faces its own irrigation problems, is headed for a similar fate.

A deeper understanding of soil and its management, as explained in this exhibition, could lead to solutions for these global problems. As Franklin D. Roosevelt said, "The nation that destroys its soil, destroys itself."

Amber Dance is a News Intern in Nature's Washington DC office.

See http://forces.si.edu/soils/index.html for more details. 